\title{
The effect of single-bulb garlic oil extract toward the hematology and histopathology of the liver and kidney in mice
}

\author{
Sri Rahayu Lestari ${ }^{\oplus *}$, Muhaimin Rifai \\ ${ }^{1}$ Department of Biology, Faculty of Mathematics and Natural Sciences, Universitas Negeri Malang (State University of \\ Malang), East Java, Indonesia, 'Department of Biology, Faculty of Mathematics and Natural Sciences, Brawijaya University, \\ East Java, Indonesia
}

\begin{abstract}
Single garlic has been used as a traditional medicine for hypercholesterolemia and increasing stamina. The aim of this research was to analyze the effect of single-bulb garlic oil (SGO) extract toward hematology and histopathology liver and kidney in mice. Male mice (strain Balb-C, 12 weeks old, weight of $28 \pm 3 \mathrm{~g}$ ) was treated by SGO for 28 days (once per days) with various doses K- (Normal); K+ (SGO $0.0 \mathrm{mg} / \mathrm{kg}$ BW); T1 (SGO 6.25 mg/kg BW); T2 (SGO 12.5 mg/kg BW); T3 (SGO 25.0 mg/kg BW); T4 (SGO $50.0 \mathrm{mg} / \mathrm{kg} \mathrm{BW}$ ). The end of the treated mice was sacrificed. Blood was collected to analyze hematology. Liver and kidney were collected then made microanatomy slide with Hematoxylin-Eosin staining. Parameters of hematology are the levels of hemoglobin, hematocrit, number of erythrocytes, and number of leukocytes. Histopathology of liver and kidney determine by cell necrosis. The result of the research showed that SGO increased the number of erythrocytes and leucocytes but there is no effect on the levels of hemoglobin and hematocrit. Histopathology on liver and kidney showed there is no effect in necrosis. The conclusion is the single-bulb garlic oil extract safe if consumed continuously
\end{abstract}

Keywords: Hematology. Histopathology. Single-bulb garlic oil extract.

\section{INTRODUCTION}

Garlic (Allium sativum) belongs to the Liliaceae family that all have common characteristics, such as being herbaceous perennial plants that form a tuber (Arzanlou, Bohlooli, 2010). Garlic bulb are the part of the plant that many people use for treatment and health care. Some diseases commonly treated with garlic are cancer, diabetes mellitus, and hypercholesterolemia (Ried, Frank, Stocks, 2013). Hypercholesterolemia is an increase in cholesterol levels that can be accompanied by an increase in lowdensity lipoprotein (LDL). High LDL levels increase the risk of and stimulate some diseases, such as hypertension, diabetes, atherosclerosis and other cardiovascular conditions (Wright, Aronne, 2012).

The main active ingredients of garlic bulb are sulfur compounds (Lawson, Larry, 1998; Iciek, Kwiecień, Włodek, 2009; Touloupakis, Ghanotakis, 2010) including diallyl disulfide, diallyl trisulfide, S-allyl cysteine, allyl disulfide (Block, 1985; Yoo et al., 2010; Block et al.,

\footnotetext{
*Correspondence: S. R. Lestari. Department of Biology, Faculty of Mathematic and Natural Sciences, Universitas Negeri Malang (State University of Malang), East Java, Indonesia. Jl. Semarang no 5, Malang, Indonesia 65145. Phone: +62-341-558077; Fax:+62-341-558077. E-mail: srirahayulestari@um.ac.id
}

2010), alliin (Chung, 2006), allicin; and a one (Ledezma, Apitz-Castro, 2006). Garlic has several important enzymes, namely allinase, peroxidase and myosinase (Bhandari, 2012). Some studies have shown that garlic has a high effectiveness against hypercholesterolemia (Gebreyohannes, Gebreyohannes, 2013), hypertension (Bhandari, 2012) and as an antioxidant (Rahman, Fazlic, Saad, 2012). Garlic is also potential as an antimicrobial (Benkeblia, 2004), anti-parasite and anti-diabetic agent (Gebreyohannes, Gebreyohannes, 2013). The use of garlic in maintaining stamina and against disease is through increased monocyte and macrophage phagocytosis activity (Agnesa, Susilo, Lestari, 2017), i.e., as an immunostimulant (Bayan, Koulivand, Gorji, 2014).

Garlic has several varieties, one of which is singlebulb garlic (Sethi et al., 2014). In Indonesia, the singlebulb garlic variety is known as Bawang lanang. Singlebulb garlic is a garlic that only consists of one bulb when it grows in an inappropriate environment. Single-bulb garlic is only found in certain areas in Indonesia. One of these garlic-producing areas is Ngadas district in Malang Regency. Single-bulb garlic has a strong pungent and acrid taste compared with multi-bulb garlics (Bharat, Alankruta, Harischa, 2013). Single-bulb garlic is a plant 
usually consumed in Indonesia society to maintain stamina and prevent various diseases caused by hyperlipidemia. Studies of the effects of continuous single-bulb garlic consumption have not been reported. Based on that description, we analyze the effects of single-bulb garlic oil extract (SGO) on hematology and histopathology of liver and kidney when continuously consumed.

\section{MATERIAL AND METHODS}

\section{Preparation of Single Garlic Oil Extract (SGO)}

Single-bulb garlic oil extract was obtained by Soxhlet extraction with $n$-hexane at UPT Material Medica Batu. A total of $1 \mathrm{~kg}$ of garlic was dried at $50^{\circ} \mathrm{C}$, mashed, and resulting in $0.3 \mathrm{~kg}$ of dried garlic powder. The garlic powder was put into thimble extractor, then $1 \mathrm{~L}$ hexane was added as a solvent. The soxhletation process was run for 18 hours; the result was evaporated using a rotary evaporator for 3 hours. The result of the soxhletation process was $3 \mathrm{mg}$ of garlic oil extract. The dose of SGO for treatment was $6.25 \mathrm{mg} / \mathrm{kg} \mathrm{BW}, 12.5 \mathrm{mg} / \mathrm{kg} \mathrm{BW}$, $25.0 \mathrm{mg} / \mathrm{kg} \mathrm{BW}$, and $50.0 \mathrm{mg} / \mathrm{kg} \mathrm{BW}$. SGO extract was diluted with corn oil for treatment.

\section{LC-MS-MS analysis}

A $1 \mathrm{~mL}$ sample of SGO was inserted into a $25 \mathrm{~mL}$ centrifuge tube. Then $14 \mathrm{~mL}$ of $2.5 \%$ formic acid in water was added, and the sample homogenized using a vortex for 30 minutes. After that, the sample was centrifuged at $4000 \mathrm{rpm}$ for 10 minutes at room temperature. The supernatant was transferred in aliquots of as much as $1.4 \mathrm{~mL}$ to $1.5 \mathrm{~mL}$ centrifuge tubes and centrifuged again at $13000 \mathrm{rpm}$ for 30 minutes. The supernatant was transferred into a micro-tube and the extract diluted with acetonitrile (50 $\mu \mathrm{L}$ extract $+950 \mu \mathrm{L}$ acetonitrile), homogenized, and centrifuged at $5900 \mathrm{rpm}$ for 30 minutes. The supernatant was then transferred to the micro-tube auto-sampler for injection into the LC-MS machine.

\section{Experimental design and treatment}

This study used Balb-C male mice aged 12 weeks with a weight of $28 \pm 3 \mathrm{~g}$ as experimental animals. The mice were acclimatized for 7 days and given standard feed. During acclimatization, the body weight and the behavior of mice were evaluated. Thirty treatment animals were divided into six treatment groups: K- (normal), $\mathrm{K}+(\mathrm{SGO} 0 \mathrm{mg} / \mathrm{kg} \mathrm{BW}) ; \mathrm{T} 1$ (SGO $6.25 \mathrm{mg} / \mathrm{kg} \mathrm{BW}), \mathrm{T} 2$ (SGO $12.5 \mathrm{mg} / \mathrm{kg} \mathrm{BW}$ ), T3 (SGO $25.0 \mathrm{mg} / \mathrm{kg} \mathrm{BW}$ ), T4
(SGO $50.0 \mathrm{mg} / \mathrm{kg} \mathrm{BW}$ ). The doses used in this study were based on the dose levels of daily consumption of humans (Lash et al., 1998; Koscielny et al., 1999; WHO, 1999). The SGO was given orally, as much as $0.3 \mathrm{~mL}$ per day for 28 days (BPOM, 2017). On the $29^{\text {th }}$ day, the mice were sacrificed using inhalation anesthesia (isoflurane 4\%). The animal treatment protocols were approved by Ethical Clearance of Republic Indonesia No. 880-KEP-UB.

\section{Blood hematology analysis}

Analysis of blood hematology included hemoglobin level indicator, hematocrit level, erythrocyte number, and leukocyte number. Hemoglobin level (\%) was measured using a hemoglobin Tall Quist scale. Hematocrit level (\%) was measured when collecting blood put in microhematocrit heparinized tubes then centrifuged. The erythrocytes and leukocytes were counted directly under 400x magnification using a Neubauer chamber (Bastidas, 2017).

\section{Histopathology of liver and kidney}

Histopathological measurement, liver, and kidney were fixed with $10 \%$ formalin solution. The liver and kidney of the mice were embedded in paraffin, sectioned into $5 \mu \mathrm{m}$-thick sections and stained with hematoxylineosin (HE). The amount of necrosis was evaluated using semi-quantitative methods by a NASH CRN scoring system (0-3), in which $0=$ normal, $1=<25 \%$ necrosis, $2=25-50 \%$ necrosis, and $3=>50 \%$ area of necrosis (Palipoch, Punsawad, 2013; Brunt, 2016).

\section{Data analysis}

Data on the hemoglobin level, total erythrocyte, total leukocyte, necrosis on liver cells, kidney tubules and kidney glomerulus were analyzed by one-way ANOVA $(p<0.01)$ followed by a Tukey post-hoc test. Data are represented as the mean \pm standard deviation (SD)

\section{RESULTS AND DISCUSSION}

\section{SGO active compounds}

The results of LC-MS analysis showed that the most abundant active compounds in the SGO extract were alliin, allicin, and ajoene ( $\mathrm{Z}$ and $\mathrm{E}$ ), with concentrations of $41 \mathrm{mg} / \mathrm{mL}, 26 \mathrm{mg} / \mathrm{mL}, 25 \mathrm{mg} / \mathrm{mL}$, and $11 \mathrm{mg} / \mathrm{mL}$, respectively. The thiosulfate compounds are a muchstudied compound of the Allium species. The compound 
is formed from S-alk(en)yl-1-cysteine-S-oxide contained in the cytoplasm, which then undergoes an enzymatic reaction catalyzed by allinase. Thiosulfate compounds have different components in each species of allium according to their precursor compound. The most commonly found compound is alliin; in garlic, alliin is the dominant compound found in garlic, which is the allicin precursor. The amino acid alliin is an alkyl amino extracted from cysteine sulfoxide. Garlic contains alliin compounds $0.6-14 \%$ of fresh garlic weight, and about $2,500-4,500 \mathrm{mg}$ allicin per gram of fresh garlic weight (Mardomi, 2017).

Decomposed Allicin will produce several organosulfur products one of which is ajoene (Mardomi, 2017). Allicin compounds are considered to have many benefits such as being antibacterial, antiviral, antifungal and anti-parasitical agents. Derivative compounds such as ajoene can inhibit the growth of gram-positive and gramnegative bacteria (Cavallito, Bailey, 1944).

\section{Blood haematology of mice}

The results of the body weight, the calculation of hemoglobin level, total erythrocyte and total leukocyte are shown in Tables I and II. Table I shows that there was not any difference in the body weight of mice at the end of the treatment in all groups. Table II shows that the provision of SGO did not have a significant effect on the percentage of Hb levels; the higher the SGO doses given did not effect an increase of $\mathrm{Hb}$ percentage. The average hematocrit of mice on the various treatments also showed no difference; the SGO gave neither have any effect on the volume of the precipitating red blood nor the plasma volume. Thus, SGO given to the mice for 28 days did not appear to have a harmful physiological effect (Ried, Travica, Sali, 2016; Haseeb et al., 2018).

The average number of erythrocytes in mice given SGO showed a significant difference compared with normal group $(\mathrm{p}<0.01)$. The mice were treated with SGO $6.25 \mathrm{mg} /$ $\mathrm{kg} \mathrm{BW}$ showed an increase in the number of erythrocytes compared to the normal and untreated mice. The higher of SGO doses were given, the higher the number of erythrocytes. The increasing number of erythrocytes did not affect the blood hematocrit condition. Thus, the provision of SGOs did not have any adverse effects. As long as the blood hematocrit is usually maintained, the mice should be in good condition (Restell et al., 2014).

TABLE I - The average of mice body weight (initial, final, and difference)

\begin{tabular}{lccc}
\hline Treatment & $\begin{array}{c}\text { Average of initial body } \\
\text { Weight (g) }\end{array}$ & $\begin{array}{c}\text { Average of final body } \\
\text { Weight (g) }\end{array}$ & $\begin{array}{c}\text { Average of difference body } \\
\text { Weight (g) }\end{array}$ \\
\hline $\mathrm{K}-(\mathrm{Normal})$ & $26.2 \pm 1.3^{\mathrm{a}}$ & $30.1 \pm 1.4^{\mathrm{a}}$ & $3.9^{\mathrm{a}} \pm 0.7^{\mathrm{a}}$ \\
$\mathrm{K}+(\mathrm{SGO} 0 \mathrm{mg} / \mathrm{kg} \mathrm{BW}$ & $26.6 \pm 1.6^{\mathrm{a}}$ & $31.6 \pm 2.1^{\mathrm{a}}$ & $5.0 \pm 0.4^{\mathrm{a}}$ \\
$\mathrm{T} 1(\mathrm{SGO} 6.25 \mathrm{mg} / \mathrm{kg} \mathrm{BW})$ & $28.6 \pm 1.5^{\mathrm{a}}$ & $30.8 \pm 1.3^{\mathrm{a}}$ & $4.0 \pm 0.7^{\mathrm{a}}$ \\
$\mathrm{T} 2(\mathrm{SGO} 12.5 \mathrm{mg} / \mathrm{kg} \mathrm{BW})$ & $27.6 \pm 1.8^{\mathrm{a}}$ & $30.0 \pm 1.8^{\mathrm{a}}$ & $2.4 \pm 0.8^{\mathrm{a}}$ \\
$\mathrm{T} 3(\mathrm{SGO} 25 \mathrm{mg} / \mathrm{kg} \mathrm{BW})$ & $27.0 \pm 1.6^{\mathrm{a}}$ & $31.0 \pm 1.3^{\mathrm{a}}$ & $4.0 \pm 1.0^{\mathrm{a}}$ \\
$\mathrm{T} 4(\mathrm{SGO} 50 \mathrm{mg} / \mathrm{kg} \mathrm{BW}$ & $27.0 \pm 1.6^{\mathrm{a}}$ & $31.2 \pm 1.3^{\mathrm{a}}$ & $4.2 \pm 0.8^{\mathrm{a}}$ \\
\hline
\end{tabular}

Description: K- (Normal); K+ (SGO 0 mg/kg BW); T1 (SGO 6.25 mg/kg BW); T2 (SGO 12.5 mg/kg BW); T3 (SGO 25 mg/kg $\mathrm{BW}) ; \mathrm{T} 4$ (SGO $50 \mathrm{mg} / \mathrm{kg} \mathrm{BW}$ ). The same notation shows there is no difference result.

TABLE II - The average of hemoglobin level, blood hematocrit, total erythrocyte and total leucocyte in mice

\begin{tabular}{|c|c|c|c|c|}
\hline Treatment & $\begin{array}{c}\text { Average of } \mathrm{Hb} \\
\text { Level (\%) }\end{array}$ & $\begin{array}{c}\text { Average of Blood } \\
\text { Hematocrit (\%) }\end{array}$ & $\begin{array}{c}\text { Average of total } \\
\text { erythrocytes }\left(\mathrm{mm}^{3}\right)\end{array}$ & $\begin{array}{l}\text { Average of total } \\
\text { leukocytes }\left(\mathrm{mm}^{3)}\right.\end{array}$ \\
\hline$\overline{\mathrm{K}-\text { (Normal) }}$ & $60.0 \pm 0.0^{\mathrm{a}}$ & $50^{\mathrm{a}}$ & $3.92 .10^{6} \pm 1184^{\mathrm{a}}$ & $2600.0 \pm 605^{\text {a }}$ \\
\hline $\mathrm{K}+(\mathrm{SGO} 0.0 \mathrm{mg} / \mathrm{kg} \mathrm{BW})$ & $70.0 \pm 0.0^{\mathrm{a}}$ & $52^{\mathrm{a}}$ & $3.94 .10^{6} \pm 1150^{\mathrm{a}}$ & $2775.5 \pm 370^{\mathrm{a}}$ \\
\hline $\mathrm{T} 1(\mathrm{SGO} 6.25 \mathrm{mg} / \mathrm{kg} \mathrm{BW})$ & $67.5 \pm 5.0^{\mathrm{a}}$ & $54^{\mathrm{a}}$ & $6.02 .10^{6} \pm 4468^{b}$ & $2900.0 \pm 653^{\mathrm{a}}$ \\
\hline $\mathrm{T} 2(\mathrm{SGO} 12.5 \mathrm{mg} / \mathrm{kg} \mathrm{BW})$ & $69.3 \pm 1.5^{\mathrm{a}}$ & $52^{\mathrm{a}}$ & $9.79 .10^{6} \pm 9688^{c}$ & $2950.0 \pm 660^{\mathrm{a}}$ \\
\hline T3 (SGO $25.0 \mathrm{mg} / \mathrm{kg} \mathrm{BW})$ & $60.0 \pm 11.0^{\mathrm{a}}$ & $50^{\mathrm{a}}$ & $8.93 .10^{6} \pm 2917^{c}$ & $7337.5 \pm 765^{b}$ \\
\hline $\mathrm{T} 4(\mathrm{SGO} 50.0 \mathrm{mg} / \mathrm{kg} \mathrm{BW})$ & $60.0 \pm 0.0^{\mathrm{a}}$ & $50^{\mathrm{a}}$ & $8.08 .10^{6} \pm 1106^{\mathrm{c}}$ & $10987.5 \pm 189^{c}$ \\
\hline
\end{tabular}

Description: K- (Normal); K+ (SGO 0 mg/kg BW); T1 (SGO 6.25 mg/kg BW); T2 (SGO 12.5 mg/kg BW); T3 (SGO 25.0 mg/kg $\mathrm{BW}) ; \mathrm{T} 4$ (SGO $50.0 \mathrm{mg} / \mathrm{kg} \mathrm{BW})$. The same notation shows there is no difference result. 
The same trend occurred in the number of leukocytes. The higher the doses given, the higher the number of leukocytes produced $(\mathrm{p}<0.01)$. The increase in the number of leukocytes due to the provision of garlic is associated with its function as immunostimulant (Nwabueze, 2012). Garlic contains sulfur compounds that act to initiate an increase in the immune system (Iciek et al., 2009). The increasing number of leukocytes due to the provision of SGO is associated with an increase of the leukocyte phagocytic capacity (Santos et al., 2012; Yamashita et al., 2015; Agnesa, Susilo, Lestari, 2017). The provision of garlic can activate non-specific and specific defense mechanisms (Rahman, Billington, 2000). Several studies have shown that allicin from SGO may increase the production of interleukin-2 and IL-12, and TNF- $\alpha$ from splenocytes (Wang et al., 2010; Schäfer, Kaschula, 2014; Kim, 2016; Lestari, Rifa'i, 2018)) and increase macrophage metabolism activity.

\section{The number of necrosis cells in liver cells and kidney}

The effect of single garlic extract on the damage of liver cells and kidney cells was determined by assessment of cell necrosis. The results of the calculation of the necrosis average on the liver cells, kidney tubular cells and kidney glomerulus cells are shown in Table III.

The average of scoring system cells undergoing necrosis in the liver was 19.9. While in the glomerulus cells and tubular cells, the highest average of necrosis was 23.1 and 21.1. The calculation of necrosis cells in the liver as well as the tubular and glomerular kidney tissue did not show any difference in the various treatments. Thus, the provision of SGO does not have any effect on the number of cells undergoing necrosis in various groups.
The microanatomy of the liver, tubular and glomerular kidney are shown in Figures 1 and 2.

After oral administration, the SGO will be absorbed by the intestine, passed through the blood vessel through the portal vein hepatica, then metabolized in the liver. The active compound from garlic extracts such as allicin, alliin, ajoene, and S-Allyl cysteine are found distributed in serum, liver, and kidney (Gao et al., 2013). According to an analysis about safety and toxicity, active compounds from garlic extract can passed through blood-brain barrier permeability (BBB-permeability). Drugs and active compounds that can pass through the BBB have an ability to decreases residual disease and toxicity and increased the efficiency of active compound for pharmacology activity in the brain. However, active compounds from garlic extract show no side effects (Jouyban, Soltani, 2012; Shaik et al., 2016). Shaik et al. (2016) showed that rats were given garlic for 6 months did not reveal any toxic effects.

Drugs that are administered orally will undergo biotransformation in the body. The process of drug biotransformation requires an enzyme from the Cytochrome P450 (CYP450s) (Gao et al., 2013). Single-bulb active garlic compound is not as an inhibitor or substrate of CYP2D6 isoenzymes so these active compounds will be metabolize by the body without any obstacles. CYP2D6 is one of the isoenzymes of CYP450 responsible for the metabolism of the drug in the liver. A drug or compound may be a CYP isoenzyme inhibitor or a substrate for the isoenzyme. If the drug becomes an inhibitor and is a substrate for the same CYP isoenzymes, then drug metabolism will be delayed (Badyal, Dadhich, 2001).

Drugs are usually eliminated after metabolism in the body. Drug excretion can be determined by total clearance

TABLE III - The average number of necrosis cells in mice treated with single-garlic oil extract with various concentration

\begin{tabular}{lcccccc}
\hline & \multicolumn{2}{c}{ Liver cells } & \multicolumn{2}{c}{ Tubular cells } & \multicolumn{2}{c}{ Glomerolus Cell } \\
\cline { 2 - 7 } Treatment & $\begin{array}{c}\text { The average } \\
\text { of necrosis } \\
\text { cell }\end{array}$ & $\begin{array}{c}\text { The average } \\
\text { of normal } \\
\text { cell }\end{array}$ & $\begin{array}{c}\text { The average } \\
\text { of necrosis } \\
\text { cell }\end{array}$ & $\begin{array}{c}\text { The average } \\
\text { of normal } \\
\text { cell }\end{array}$ & $\begin{array}{c}\text { The average } \\
\text { of necrosis } \\
\text { cell }\end{array}$ & $\begin{array}{c}\text { The average } \\
\text { of normal } \\
\text { cell }\end{array}$ \\
\hline $\mathrm{K}-($ Normal) & $13.1^{\mathrm{a}}$ & $86.9^{\mathrm{a}}$ & $12.8^{\mathrm{a}}$ & $87.2^{\mathrm{a}}$ & $14.2^{\mathrm{a}}$ & $85.8^{\mathrm{a}}$ \\
$\mathrm{K}+(\mathrm{SGO} 0.0 \mathrm{mg} / \mathrm{kg} \mathrm{BW})$ & $19.9^{\mathrm{a}}$ & $80.1^{\mathrm{a}}$ & $21.1^{\mathrm{a}}$ & $78.9^{\mathrm{a}}$ & $23.1^{\mathrm{a}}$ & $76.9^{\mathrm{a}}$ \\
$\mathrm{T} 1$ (SGO $6.25 \mathrm{mg} / \mathrm{kg} \mathrm{BW})$ & $12.6^{\mathrm{a}}$ & $87.4^{\mathrm{a}}$ & $18.1^{\mathrm{a}}$ & $81.9^{\mathrm{a}}$ & $14.2^{\mathrm{a}}$ & $85.8^{\mathrm{a}}$ \\
$\mathrm{T} 2(\mathrm{SGO} 12.5 \mathrm{mg} / \mathrm{kg} \mathrm{BW})$ & $13.2^{\mathrm{a}}$ & $86.8^{\mathrm{a}}$ & $17.1^{\mathrm{a}}$ & $82.9^{\mathrm{a}}$ & $12.2^{\mathrm{a}}$ & $87.8^{\mathrm{a}}$ \\
$\mathrm{T} 3$ (SGO 25.0 $\mathrm{mg} / \mathrm{kg} \mathrm{BW})$ & $11.7^{\mathrm{a}}$ & $88.3^{\mathrm{a}}$ & $13.8^{\mathrm{a}}$ & $86.2^{\mathrm{a}}$ & $9.4^{\mathrm{a}}$ & $90.6^{\mathrm{a}}$ \\
$\mathrm{T} 4$ (SGO 50.0 $\mathrm{mg} / \mathrm{kg} \mathrm{BW})$ & $9.8^{\mathrm{a}}$ & $90.2^{\mathrm{a}}$ & $11.7^{\mathrm{a}}$ & $88.3^{\mathrm{a}}$ & $8.4^{\mathrm{a}}$ & $91.6^{\mathrm{a}}$ \\
\hline
\end{tabular}

Description: K- (Normal); K+ (SGO 0 mg/kg BW); T1 (SGO 6.25 mg/kg BW); T2 (SGO 12.5 mg/kg BW); T3 (SGO 25 mg/kg $\mathrm{BW})$; T4 (SGO $50 \mathrm{mg} / \mathrm{kg} \mathrm{BW).} \mathrm{The} \mathrm{same} \mathrm{notation} \mathrm{shows} \mathrm{there} \mathrm{is} \mathrm{no} \mathrm{difference} \mathrm{result.}$ 

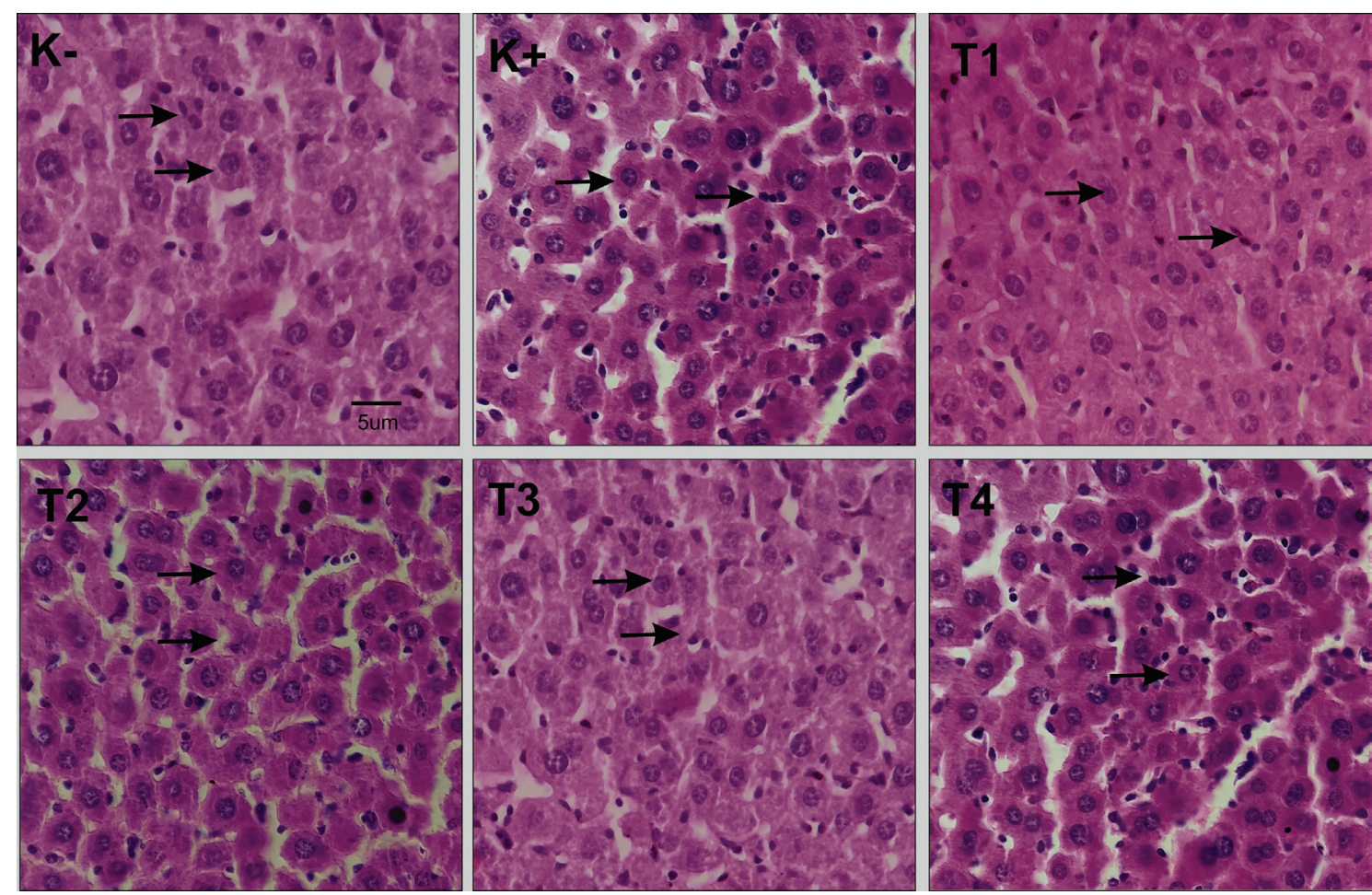

FIGURE 1 - Normal and necrosis cell liver, staining using Hematoxylin-Eosin. Arrow = necrosis cell and normal cell (400 X magnification).
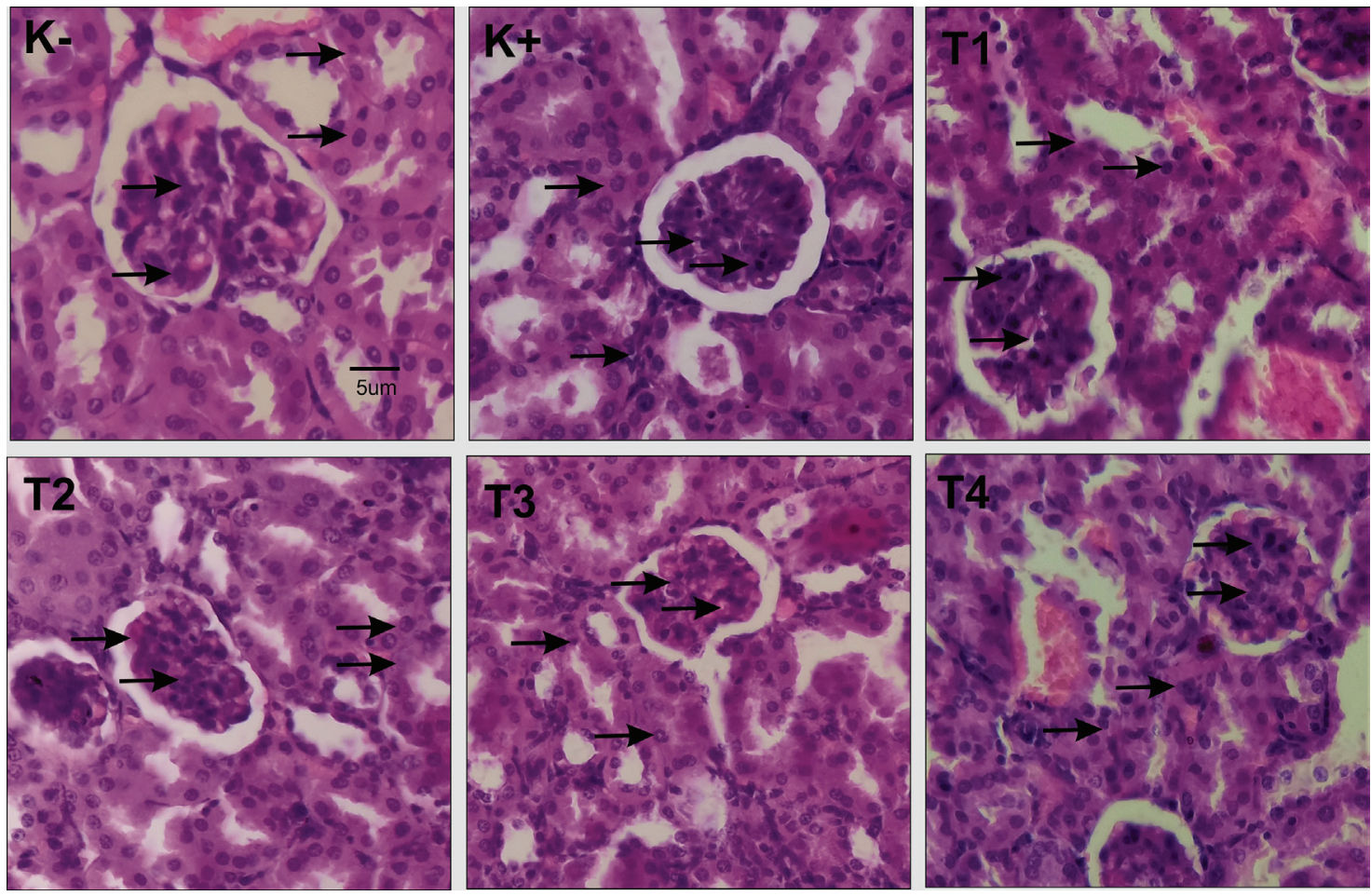

FIGURE 2 - Normal and necrosis cell glomerular and tubules in kidney, staining using Hematoxylin-Eosin. Arrow = necrosis cell and normal cell (400 X magnification).

and organic cation transporters 2 (OCT2) substrate (Beaumont et al., 2014). Total clearance is drug excretion through a renal process in which the drug passes through the kidney to the bladder and is removed through the urine. In the kidneys, there is a transporter to secrete drugs to urine, i.e., organic cation transporters (OCTs). Compounds 
in garlic are not a substrate of Renal OCT. Organic cation transporters are essential transporters for drug elimination from plasma as well as in the kidney. Most drugs can be an OCT2 substrate or inhibitor. If a drug becomes a substrate of OCT, then the performance of OCT2 will be inhibited, so the drug cannot be eliminated thoroughly (Motohashi and Inui, 2013). This study suggests that single garlic might be considered as an alternative herbal treatment and safely used continuously.

\section{CONCLUSION}

This study showed that SGO extracts increase number of erythrocytes and leucocytes, but had no affect the levels of hemoglobin and hematocrit. Histopathology on liver and kidney after SGO consumption showed there is no effect on necrosis in these organs.

\section{CONFLICT OF INTEREST STATEMENT}

We declare that we have no conflict of interest

\section{ACKNOWLEDGMENT}

The research supported by UPT Balai Materia Medika-Batu and funding by Ministry of Research, Technology and Higher Education of Republic Indonesia no grand 3.4.8/UN.32.14.LT/2017.

\section{REFERENCES}

Agnesa OS, Susilo H, Lestari SR. The immunostimulant activity of a single garlic extract on the mice induced by Escherichia coli. Pharmaciana. 2017;7(1):105-112.

Arzanlou M, Bohlooli S. Introducing of green garlic plant as a new source of allicin. Food Chem. 2010;120(1):179-183.

Badyal DK, Dadhich AP. Cytochrome P450 and drug interactions. Indian J Pharmacol. 2001;33:248-259.

Beaumont C, Young C, Cavalier T, Young MA. Human absorption, distribution, metabolism and excretion properties of drug molecules: a plethora of approaches. Brit J Clin Pharmacol. 2014;78(6):1185-1200.

Bharat P, Alankruta D, Harischa H. Detail comparative pharmacognostical study of single clove garlic. Universal J Pharm. 2013;2(2):181-186.
Bastidas O. Cell is counting with Neubauer Chamber basic hemocytometer usage. 2017. Retrieved from: http://www. celeromics.com/en/resources/docs/Articles/Cell-countingNeubauer-chamber.pdf.

Bayan L, Koulivand PH, Gorji A. Garlic: a review of potential therapeutic effects. Avicenna J Phytomed. 2014;4(1):1-14.

Benkeblia N. Antimicrobial activity of essential oil extracts of various onions (Allium cepa) and garlic (Allium sativum). LWT Food Sci Technol. 2004;37(2):263-268.

Bhandari P. Garlic (Allium sativum L.): A review of potential therapeutic applications. Int J Green Pharm. 2012;6(2):118.

Block E. The chemistry of garlic and onions. Scient Am. 1985;252(3):114-118.

Block E, Dane AJ, Thomas S, Cody RB. Applications of direct analysis in real time mass spectrometry (DART-MS) in Allium chemistry. 2-propenesulfenic and 2-propenesulfinic acids, diallyl trisulfide $\mathrm{S}$-oxide, and other reactive sulfur compounds from crushed garlic and other alliums. J Agric Food Chem. 2010;58(8):4617-4625.

BPOM of Republic of Indonesia. The National Agency of Drug and Food Control of Republic of Indonesia. 2017. Available from: http://www.pom.go.id/index.php/io.

Brunt EM. Nonalcoholic fatty liver disease: pros and cons of histologic systems of evaluation. Int J Molecular Sci. 2016;17(97):1-10.

Cavallito CJ, Bailey JH. Allicin, the antibacterial principle of Allium sativum. I. Isolation, physical properties, and antibacterial action. J Am Chem Soc. 1944;66(11): 1950-1951.

Chung LY. The antioxidant properties of garlic compounds: allyl cysteine, alliin, allicin, and allyl disulfide. J Med Food. 2006;9(2):205-13.

Gao C, Jiang X, Wang H, Zhao Z, Wang W. Drug metabolism and pharmacokinetics of organosulfur compounds from garlic. Drug Metabol Toxicol. 2013;4(5):1-10.

Gebreyohannes G, Gebreyohannes M. Medicinal values of garlic: A review. Int J. Med Med Sci. 2013;5(9):401-408. 
Haseeb MT, Bashir S, Hussain MA, Ashraf MU, Erum A, Naeem-ul-Hassan M. Acute toxicity study of a polysaccharide based hydrogel from linseed for potential use in drug delivery system. Braz. J. Pharm. Sci. 2018;54(2):e17459: 1-7.

Iciek M, Kwiecień I, Włodek L. Biological properties of garlic and garlic-derived organosulfur compounds. Environ Mol Mutagen. 2009;50(3):247-65.

Jouyban A, Soltani S. Blood-Brain Barrier Permeation. Toxic Drug Test. 2012;1-24.

Kim HK. Garlic supplementation ameliorates UV-Induced photoaging in hairless mice by regulating antioxidative activity and MMPs expression. Molecules. 2016;21(1):70.

Koscielny J, Klüssendorf D, Latza R, Schmitt, R, Radtke H, Siegel G, Kiesewetter $H$. The antiatherosclerotic effect of Allium sativum. Atherosclerosis. 1999;144(1):237-249.

Lash JP, Cardoso LR, Mesler PM, Walczak DA, Pollak R. The effect of garlic on hypercholesterolemia in renal transplant patients. Transplant Proc. 1998;30(1):189-191.

Lawson Larry D. Garlic: A review of its medicinal effects and indicated active compounds. Phytomed Eur. 1998;691(1):176209.

Ledezma E, Apitz-Castro R. Ajoene the main active compound of garlic (Allium sativum): a new antifungal agent. Rev Iberoam Micol. 2006;23(2):75-80.

Lestari SR, Rifa'i M. Regulatory T cells and anti-inflammatory cytokine profile of mice fed a high-fat diet after single-bulb garlic (Allium sativum L.) oil treatment. Tropical Journal of Pharmaceutical Research, November, 2018; 17 (11): 2157-2162.

Nwabueze TU. African breadfruit (Treculia Africana) SEED physical dimensions considerable for kernel cleaning and seed type selection. J Food Proc Eng. 2012;35(5):687-694.

Mardomi R. Determining the chemical compositions of garlic plant and its existing active element. IOSR J Appl Chem. 2017;10(1):63-66.

Motohashi H, Inui K. Organic cation transporter OCTs (SLC22) and MATEs (SLC47) in the human kidney. J Am Assoc Pharm Sci. 2013;15(2):581-588.
Palipoch S, Punsawad C. Biochemical and histological study of rat liver and kidney injury induced by cisplatin. J Toxicol Pathol. 2013;26(3):293-299.

Rahman K, Billington D. Human nutrition and metabolism dietary supplementation with aged garlic extract inhibits ADP-induced platelet aggregation in humans. J Nutr. 2000;130(11):2662-2665.

Rahman MM, Fazlic V, Saad NW. Antioxidant properties of raw garlic (Allium sativum) extract. Int Food Res J. 2012;19(2):589591.

Restell TI, Porfirio LC, Souza AS, Silva IS. Hematology of Swiss mice (Mus musculus) of both genders and different ages. Acta Cirúrg Bras. 2014;29(5):306-12.

Ried K, Frank OR, Stocks NP. Aged garlic extract reduces blood pressure in hypertensives: a dose-response trial. Eur J Clin Nutr. 2013;67(1):64-70.

Ried K, Travica N, Sali A. The effect of aged garlic extract on blood pressure and other cardiovascular risk factors in uncontrolled hypertensives: The AGE at Heart trial. Integr Blood Press Control. 2016;9:9-21.

Santos AA, Ranzani-Paiva MJT, da Veiga ML, Faustino L, Egami MI. Hematological parameters and phagocytic activity in fat snook (Centropomus parallelus) bred in captivity. Fish Shellfish Immunol. 2012;33(4):953-961.

Schäfer G, Kaschula CH. The immunomodulation and antiinflammatory effects of garlic organosulfur compounds in cancer chemoprevention. Anti-Cancer Agents Med Chem. 2014;14(2):233-40.

Sethi N, Kaura S, Dilbaghi N, Parle M, Pal M. Garlic: a pungent wonder from nature. Int Res J Pharm. 2014;5(7):523-529.

Shaik R, Kumar S, Rao R, Srinivasulu MD. Critical analysis of Lasuna (Role of Lasuna in different branches of Ayurveda). J Pharm Biol Sci. 2016;11(5):46-80.

Touloupakis E, Ghanotakis DF. Nutraceutical use of garlic sulfurcontaining compounds. Adv Exp Med Biol. 2010;698:110-121.

Wang D, Feng Y, Liu J, Yan J, Wang M, Sasaki J-I, Changlong L. Black garlic (Allium sativum) extracts enhance the immune system. Med Aromat Plant Sci Biotechnol. 2010;4(1):37-40. 
World Health Organization. Monograph Selection of Medicinal Plant, vol 1. Geneva: WHO;1999. Available from: http://apps. who.int/medicinedocs/en/d/Js2200e/4.html.

Wright SM, Aronne LJ. Causes of obesity. Abdom Imag. 2012;37(5):730-732.

Yamashita T, Sasaki N, Kasahara K, Hirata K. Anti-inflammatory and immune-modulatory therapies for preventing atherosclerotic cardiovascular disease. J Cardiol. 2015;66(1):1-8.
Yoo M, Lee S, Lee S, Seog H, Shin D. Validation of highperformance liquid chromatography methods for Determination of bioactive sulfur compounds in garlic cloves. Food Sci Biotechnol. 2010;19(6):1619-1626.

Received for publication on $11^{\text {th }}$ January 2018 Accepted for publication on $22^{\text {nd }}$ June 2018 